\title{
Morphometric and Length-Weight Relationship in the Mud Crab (Scylla serrata) from Sudanese Red Sea Coast
}

\author{
Hala Gindeel Abu Bakr Ahmadoon* \\ Animal Resources Research Corporation, Fisheries Research Center Red Sea Fisheries \\ Research Station, Sudan \\ *Corresponding author
}

\begin{tabular}{l}
\hline Ke y w or d s \\
$\begin{array}{l}\text { Crab, Scylla } \\
\text { Serrata, Portunidae, } \\
\text { Sexual Secondary } \\
\text { Characters, Red Sea }\end{array}$ \\
\hline Article Info \\
\hline $\begin{array}{l}\text { Accepted: } \\
\text { 18 May } 2019 \\
\text { Available Online: } \\
\text { 10 June } 2019\end{array}$ \\
\hline
\end{tabular}

\section{A B S T R A C T}

The study, estimated to contribute to generate information to elucidate morphometrics and length-weight relationship and the relative growth of some body parts of the mud crab Scylla serrata. A total of 100 crabs were collected, from January 2018 to January 2019, from Sudanese Red Sea coast of the commercial catch land at Port Sudan. Each specimen was sexed and measured. Regression equations were calculated assuming an allometric growth equation, to determine relations between different morphometric characters in males and females, the carapace width/ length -weight relationship was estimated using the $\log$ form of the allometric growth equation. The values of the correlation coefficient $\left(\mathrm{R}^{2}\right)$ were calculated to know the accuracy of the dependent variable and the coefficient of determination. The study has shown that males are marginally heavier than females. Right chela propodus length and height are bigger in males than females, the right chela propodus length of males ranged from 7.83 to $15.44 \mathrm{~mm}$. But the crabs length and width, Abdomen length and width are bigger in females than males. The carapace width of males ranged from 11.64 to $19.95 \mathrm{~mm}$, while in females ranged from 12.73 to $20.86 \mathrm{~mm}$, and the Abdomen width of females ranged from 7.4 to $10.47 \mathrm{~mm}$, while in males ranged from 2.94 to $5.7 \mathrm{~mm}$. The right chela Propodus length and height in male and females are bigger than the left one. The results are shown that the allometric equations between the set of characters studied suggested that in most cases the relationship was negative. Growth was negatively allometric in both sexes. Carapace length against Carapace width was positively allometric for both males and females. These results of this study will make useful information, needed for the effective management and utilization of this resource in the Red Sea area.

\section{Introduction}

Crustaceans are important members of marine benthic communities. In addition to the value of the larger and more abundant species for human consumption, a tremendous variety of smaller species contribute to the complexity and functioning of ecosystems (Hamed et al., 2012). Among decapod crustaceans, the infraorder Brachyura is prominent because of its great diversity, comprising about 1271 genera and 6793 species worldwide ( $\mathrm{Ng}$ et al., 
2008; De Grave et al., 2009). In Red sea the crabs are a variety of species, of which 25 families were recorded from the Red Sea (Vine, 1980). There are some important commercial species, the most important of which is the mud crab. The mud crab (Scylla Serrata) along with most species of commercially harvested crabs belongs to the family portunidae, species in this family are usually referred to as a swimmer or paddle crabs. They are among the most valuable crab species in the world, with the bulk of their commercial production sent live to market. Mud crabs, like most intertidal organisms, respond to key factors in their environment such as temperature and salinity, constantly modifying their metabolic functions such as respiration and excretion in efforts to maintain homeostasis. the most bury live in the mud, and can tolerate wide variation in temperature (12-35C) and salinity (2-50\%). However, it has been found that their activity and feeding slows greatly in temperatures less than $20 \mathrm{c}$ (status of fisheries resources in nsw, 2008). Burrows into the mud, commonly at approximately $30^{\circ}$ to the horizontal are often used as refuges for sub adult and adult crabs (Leme, 2005; Castiglioni et al., 2011). They forage at night for food feeding mainly on molluscs, crustaceans and worms (status of fisheries resources in new, 2008). Mangrove vegetation is important to mud crabs as it provides both habitat and food supply Mud crabs can be found in a variety of microhabitats around mangrove forests (Leme, 2005; Castiglioni et al., 2011). Grows in a stepwise fashion through a succession of moults until they reach maturity after 18-24 month and death is thought to occur at a maximum of 4 years, usually found in sheltered waters and mangrove areas (status of fisheries resources in new, 2008). Studies of relative growth are often used to determine changes in the form and size of the abdomen, pleopods, or chelipeds during ontogeny. Knowledge of these distinguishing characters and size relationships in sexually mature individuals is of particular importance in the study of commercially valuable crustaceans. Such knowledge can be useful for further studies on the life history of the species and in the development of its fishery, resource management, and culture. The mathematical length-weight relationship thus yields information on the general well-being of individuals, variation in growth according to sex, size at first maturity, gonadal development, and breeding season. Study of the length-weight relationship in aquatic animals has wide application in delineating the growth patterns during their developmental pathways (Bagenal, 1978). Interest in morphological variation has long been a driving force behind many biological studies. In crustaceans, the allometric relationships between body size and various organs are used to estimate the sexual maturity, assuming that the secondary sexual characteristics appear and grow at different rates in mature and immature stages (Leme, 2005). The present study aimed to contribute to generate information to elucidate morphometrics and length-weight relationship in the mud crab, from Sudanese Red Sea coast.

\section{Materials and Methods}

Random samples of about 100 crabs of Scylla serrata, were collected from the commercial catch land at Port Sudan fish market from January 2018 to January 2019. All of the crabs used were in good condition, with the carapace intact and unbroken. In the laboratory, specimens were sexed according to secondary sexual characters (abdomen morphology and number of pleopods). Vernier calipers with an accuracy of $0.5 \mathrm{~mm}$ were used for length measurements, and the total weight of the crab was determined to the nearest gram using a digital balance $(1 \mathrm{~g})$. Carapace width $(\mathrm{CW})$ was taken as the 
distance between the tips of the posterior most lateral carapace spines. Carapace length (CL) was measured dorsally along the midline, between the frontal notch and the posterior margin of the carapace. Right chela propodus length (Ch L) was measured from the tip of the propodus' fixed finger to the base of the propodus. Propodus height $(\mathrm{Ch} \mathrm{H})$ of the same chela was measured across the widest region of the chela palm. Abdominal length was measured along the midline from the anterior margin of the first so mite to the posterior margin of the telson. Abdominal width was measured at the maximum width across the fourth so mite. To study the interrelations between different morphometric characters in males, carapace length and width was regressed on chela propodus length and chela propodus height; carapace width was regressed on chela propodus length and chela propodus height; and chela propodus length was regressed on chela propodus height. In females, carapace width and length were regressed on abdominal length and width; and abdominal width was regressed on abdominal length. Regression equations were calculated assuming an allometric growth equation $(\mathrm{Y}=\mathrm{a}+\mathrm{bX})$, to determine relations between different morphometric characters in males and females with the objective of establishing a mathematical relationship between the variables, so that if one variable is known, the other could be computed approximately. The values of the correlation coefficient $\left(\mathrm{R}^{2}\right)$ were calculated to know the accuracy of the dependent variable and the coefficient of determination. The carapace width/ length -weight relationship was estimated using the log form of the allometric growth equation $\mathrm{W}=\mathrm{aB}^{\mathrm{b}}$ (Rickter, 1973 in josileen, 2011), where $\mathrm{W}=$ expected weight, $\mathrm{B}=$ carapace width, carapace length, ' $\mathrm{a}$ ' = yintercept or the initial growth coefficient, and ' $b$ ' = the slope or growth coefficient. The values of the constants of ' $a$ ' and ' $b$ ' were calculated by the least squares method.

\section{Results and Discussion}

In population studies, morphometric analysis provides a powerful complement to genetic and environmental stock identification approaches (Cadrin, 2000) and length-weight relationships allow the conversion of growthin-length equations to growth-in-weight for use in a stock assessment model (Moutopoulos and Stergiou, 2002) and the mathematical length-weight relationship thus yields information on the general well-being of individuals, variation in growth according to sex, size at first maturity, gonadal development, and breeding season.

Study of the length-weight relationship in aquatic animals has wide application in delineating the growth patterns during their developmental pathways (Bagenal, 1978 in Josileen, 2011). Also the allometric relationships are powerful tools used by taxonomists and ecologists in the analysis of intraspecific and interspecific variation among different populations and to estimate the average size at sexual maturity, also related to environmental conditions (Costa and Soares-Gomes, 2008).

Information about individual body weightlength/width relationships in populations is important for estimating the population size of a stock, specifically for the purpose of its exploitation.

The length-width/weight relationships are regarded as more suitable for evaluating crustacean populations (Josileen, 2011); Atar and Sector, 2003; Gorce et al., 2006; Sangun et al., 2009). In this study the interrelationships between various morphometric characters, carapace width/length and chela propodus length/height, abdominal width/length in males and females were analyzed and are here presented. 


\section{Interrelationships of different morphometric characters between males and females}

The study has shown that males are marginally heavier than females. Right chela propodus length and right chela propodus height are bigger in males than females, the right chela propodus length of males ranged from 7.83 to $15.44 \mathrm{~mm}$.

But the crabas length and width, Abdomen length and width are bigger in females than males. The carapace width of males ranged from 11.64 to $19.95 \mathrm{~mm}$, while in females ranged from 12.73 to $20.86 \mathrm{~mm}$, and the Abdomen width of females ranged from 7.4 to $10.47 \mathrm{~mm}$, while in males ranged from 2.94 to $5.7 \mathrm{~mm}$. The right chelapropodus length and height in male and females are bigger than the left one. The results are given in table 1.

This agree with josileen (2011) has noted that Gross morphological differences in external anatomy between sexes are similar to those of other Portunid crabs. And agree with Shelley and Lovatelli (2011) reported that Mud crabs have claws (chelae) with different functions; the right-hand is a "crusher" and the left-hand a "cutter".

There is a significant difference in the development of male and female claws such that the weight of a large mature male's "crusher" is approximately 2.5 times that of a female claw from a crab about the same size for $S$. serrata.

However, up until a CW of approximately 10 $\mathrm{cm}$, the gross morphology of male and females are essentially the same. Differences in weight between male and female $S$. serrata are most apparent in large crabs with males of $15 \mathrm{~cm} \mathrm{CW}$ and $20 \mathrm{~cm} \mathrm{CW}$ weighs 55 percent and 80 percent, respectively, more than females of the same CW.

\section{Interrelationships between different morphometric characters}

Growth can be expressed by the increase of size, volume, wet weight or dry weight over time. Organisms that do not have an exoskeleton present a continuous growth, but in Crustacea, which have a rigid and inextensible exoskeleton, growth becomes an essentially discontinuous process.

There is a succession of molts or ecdyses, separated by an internet period (Hartnoll, 1982). According to Ribeiro et al (2013), the allometric equation is the most utilized method for analysis of growth during the ontogeny. The relationship between the size of a body part (y) compared with other body part (x), generally the carapace width $(\mathrm{CW})$, can be expressed by the equation $y=a . x b$, where the exponent $b$ is the measure of the different rates of growth of the two body parts. To estimate the coefficients of allometric equation, the data are usually logarithmized and a linear regression is fitted, and represented by the equation $\log \mathrm{y}=\log \mathrm{a}$ $+\mathrm{b} \cdot \log \mathrm{x}$, where the allometric exponent $\mathrm{b}$ is the slope of the resulting linear equation (Ribeiro et al, 2013).

The present study showed that allometric equations are indicated in tables 2 and 3. The allometric relation between the set of characters studied suggested that in most cases the relationship was negative (figs. 113).All equations of relative growth analysis are described for the relationship between Carapace width/ length and Chela propodus length/ height, distinct was obtained for males was negatively allometric.

Growth in Chela propodus length and Chela propodus height was negatively allometric. $\mathrm{R}^{2}$ is relatively was less strong except for Chela propodus length / height. This agree with josileen (2011) who investigated that 
negatively allometric for the blue swimmer crabs.

For females, the relationship was the same, and the growth in length of the carapace was also negatively allometric. $\mathrm{R}^{2}$ is relatively high in all cases.
The scatter diagram was obtained by plotting carapace length against the carapace width of individual crabs (figs 11). From the data presented, a distinct relationship was found between carapace length and carapace width, as judged from the closeness of the scatter dots, as well as from the parabolic nature of the plot.

Table.1 Total weight, carapace width/length, Abdomen width/length and chela propodus length /height in males and females of Scylla serrate

\begin{tabular}{|l|c|c|c|c|c|c|}
\hline \multicolumn{1}{|c|}{ Variable } & \multicolumn{3}{|c|}{ Male } & \multicolumn{3}{c|}{ Female } \\
\cline { 2 - 7 } & min & Max & $\begin{array}{c}\text { Mean } \pm \\
\text { SD }\end{array}$ & min & Max & $\begin{array}{c}\text { Mean } \pm \\
\text { SD }\end{array}$ \\
\hline Total weight & 261 & 1352 & $\begin{array}{c}784.73 \pm 2 . \\
4\end{array}$ & 316 & 1287 & $\begin{array}{c}771.54 \pm 2 . \\
9\end{array}$ \\
\hline Crabas length & 7.8 & 12.7 & $10.05 \pm 1.9$ & 8.64 & 13.92 & $10.98 \pm 1.4$ \\
\hline Carapace width & 11.64 & 19.95 & $14.70 \pm 2.1$ & 12.73 & 20.86 & $15.99 \pm 2.3$ \\
\hline Abdomen length & 3.03 & 8.78 & $6.66 \pm 1.5$ & 6.62 & 12.26 & $8.64 \pm 2.1$ \\
\hline Abdomen width & 2.94 & 5.7 & $3.83 \pm 0.8$ & 7.4 & 10.47 & $8.24 \pm 1.1$ \\
\hline $\begin{array}{l}\text { Right chela propodus } \\
\text { length }\end{array}$ & 7.83 & 15.44 & $11.24 \pm 1.9$ & 7.49 & 12.77 & $9.44 \pm 1.4$ \\
\hline $\begin{array}{l}\text { Right chela propodus } \\
\text { height }\end{array}$ & 3 & 7.24 & $5.18 \pm 1.1$ & 3.23 & 5.6 & $4.35 \pm 0.7$ \\
\hline $\begin{array}{l}\text { Left chela propodus } \\
\text { length }\end{array}$ & 8.61 & 13.8 & $10.85 \pm 2.3$ & 8.05 & 9.7 & $8.44 \pm 1.1$ \\
\hline $\begin{array}{l}\text { Left chela propodus } \\
\text { height }\end{array}$ & 3.71 & 6.22 & $4.93 \pm 1.4$ & 3.3 & 4.4 & $8.44 \pm 0.7$ \\
\hline
\end{tabular}

Table.2 Equations and correlation coefficient (R2) values between different variables in males of Scylla serrate

\begin{tabular}{|c|c|c|c|}
\hline $\begin{array}{l}\text { Independent } \\
\text { variable(x) }\end{array}$ & $\begin{array}{l}\text { dependent } \\
\text { variable(y) }\end{array}$ & Equations $(y=\mathbf{a}+\mathbf{b} x)$ & $\begin{array}{l}{ }^{\prime} R^{2}, \\
\text { value }\end{array}$ \\
\hline $\begin{array}{c}\text { Carapace width } \\
\text { Carapace width } \\
\text { Carapace length } \\
\text { Carapace length } \\
\text { Chela propodus } \\
\text { length }\end{array}$ & $\begin{array}{l}\text { Chela propodus } \\
\text { length } \\
\text { Chela propodus } \\
\text { height } \\
\text { Chela propodus } \\
\text { length } \\
\text { Chela propodus } \\
\text { height } \\
\text { Chela propodus } \\
\text { height }\end{array}$ & $\begin{array}{c}\mathrm{CPL}=-1.073+0.832 \mathrm{CW} \\
\mathrm{CPH}=-1.692+0.462 \mathrm{CW} \\
\mathrm{CPL}=-3.156+1.428 \mathrm{CL} \\
\mathrm{CPH}=-3.205+0.828 \mathrm{CL} \\
\mathrm{CPH}=-1.371+0.579 \\
\mathrm{CPL}\end{array}$ & $\begin{array}{l}0.733^{*} \\
0.609^{*} \\
0.771^{*} \\
0.700^{*} \\
0.907^{*}\end{array}$ \\
\hline
\end{tabular}

* Indicates highly positive allometry, significant at $1 \%$ level. 
Table.3 Equations and correlation coefficient (R2) values between different variables in females of Scylla serrata

\begin{tabular}{|c|c|c|c|}
\hline $\begin{array}{l}\text { Independent } \\
\text { variable(x) }\end{array}$ & $\begin{array}{l}\text { dependent } \\
\text { variable }(y)\end{array}$ & Equation $(y=a+b x)$ & $\begin{array}{l}{ }^{6} \mathbf{R}^{2} \text {, } \\
\text { value }\end{array}$ \\
\hline Carapace width & Abdomen width & $\mathrm{AW}=-3.867+$ & $0.981^{*}$ \\
\hline Carapace width & Abdomen length & $0.701 \mathrm{CW}$ & $0.894^{*}$ \\
\hline Carapace length & Abdomen length & $\mathrm{AL}=-6.688+0.907 \mathrm{CW}$ & $0.917^{*}$ \\
\hline Carapace length & Abdomen width & $\mathrm{AL}=-6.817+1.352 \mathrm{CL}$ & $0.951^{*}$ \\
\hline Abdomen width & Abdomen length & $\begin{aligned} \mathrm{AW} & =-3.639+1.015 \mathrm{CL} \\
\mathrm{AL} & =-1.48+1.268 \mathrm{AW}\end{aligned}$ & $0.874^{*}$ \\
\hline
\end{tabular}

* Indicates highly positive allometry, significant at $1 \%$ level.

Table.4 Equations and correlation coefficient (R2) values between Carapace width/length relationship in males and females of Scylla serrate

\begin{tabular}{|l|l|l|l|}
\hline $\begin{array}{l}\text { Independent } \\
\text { variable(x) }\end{array}$ & $\begin{array}{l}\text { dependent } \\
\text { variable(y) }\end{array}$ & $\begin{array}{l}\text { Equation }(y=\mathbf{a}+ \\
\mathbf{b} \boldsymbol{x})\end{array}$ & ${ }^{\mathbf{C}} \mathbf{R}^{\mathbf{2},}$ value \\
\hline Carapace length & $\begin{array}{l}\text { Carapace width } \\
\mathbf{C} \text { w= 0.105+ } \\
1.452 \mathrm{CL}\end{array}$ & $\mathbf{0 . 8 5 4}$ \\
\hline
\end{tabular}

* Indicates highly positive allometry, significant at $1 \%$ level.

Table.5 Power function and correlation coefficient (R2) values between Carapace width/length Total weight relationship in males and females of Scylla serrate

\begin{tabular}{|l|l|l|}
\hline Measurements & Power function & $\mathbf{R}^{\mathbf{2}}$ \\
\hline $\begin{array}{l}\text { Carapace length -Total } \\
\text { weight }\end{array}$ & $\mathrm{T} \mathrm{W}=2.873 \mathrm{C} \mathrm{L}^{2.3512}$ & 0.6299 \\
\hline $\begin{array}{l}\text { Carapace width - Total } \\
\text { weight }\end{array}$ & $\mathrm{TW}=1.7514 \mathrm{CW}^{2.2065}$ & 0.6023 \\
\hline
\end{tabular}

Table.6 t- value" for the carapace width/length and total weight relationship in males and females of Scylla serrate

\begin{tabular}{|l|l|l|l|}
\hline Relationship & sex & "t- value" & Remarks \\
\hline $\begin{array}{l}\text { Carapace length -Total } \\
\text { weight }\end{array}$ & Male & 0.593 & Significant at 1\% \\
\hline $\begin{array}{l}\text { Carapace length -Total } \\
\text { weight }\end{array}$ & female & 0.907 & Significant at 1\% \\
\hline $\begin{array}{l}\text { Carapace width - Total } \\
\text { weight }\end{array}$ & Male & 0.777 & Significant at 1\% \\
\hline $\begin{array}{l}\text { Carapace width - Total } \\
\text { weight }\end{array}$ & female & 0.939 & Significant at 1\% \\
\hline
\end{tabular}


Fig.1 Carapace width and chela propodus length in males of Scylla serrate

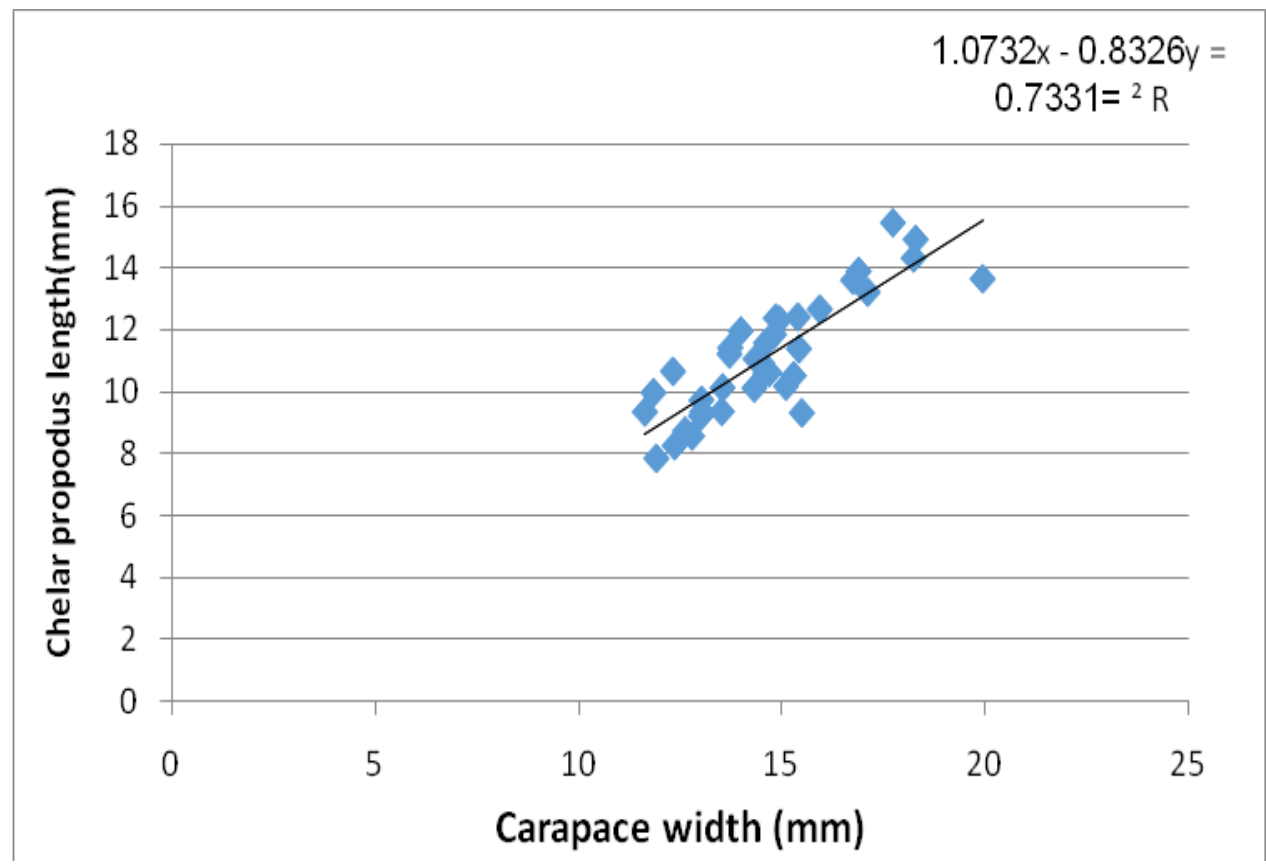

Fig.2 Carapace width and chela propodus height relationship in males of Scylla serrate

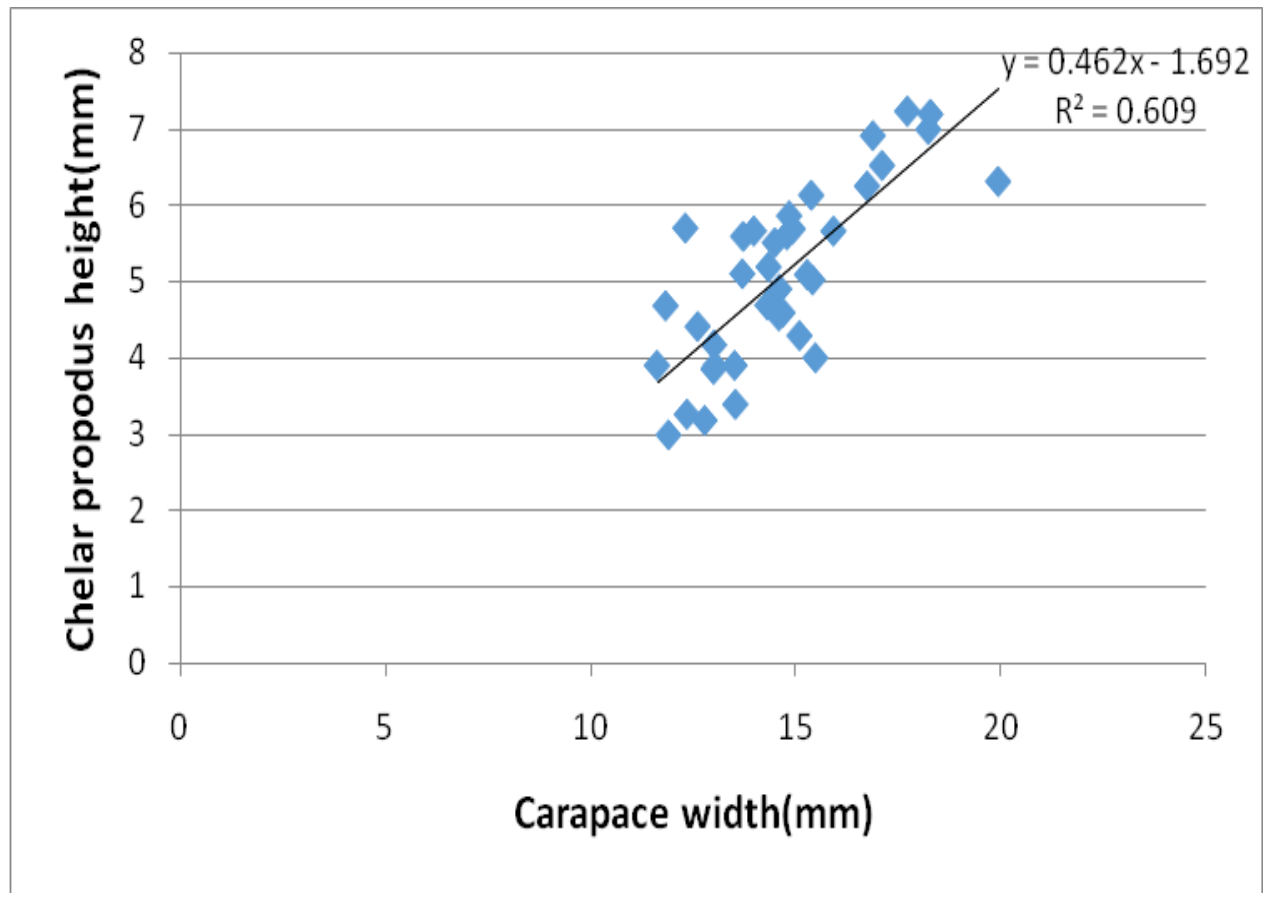


Fig.3 Carapace length and chela propodus length relationship in males of Scylla serrate

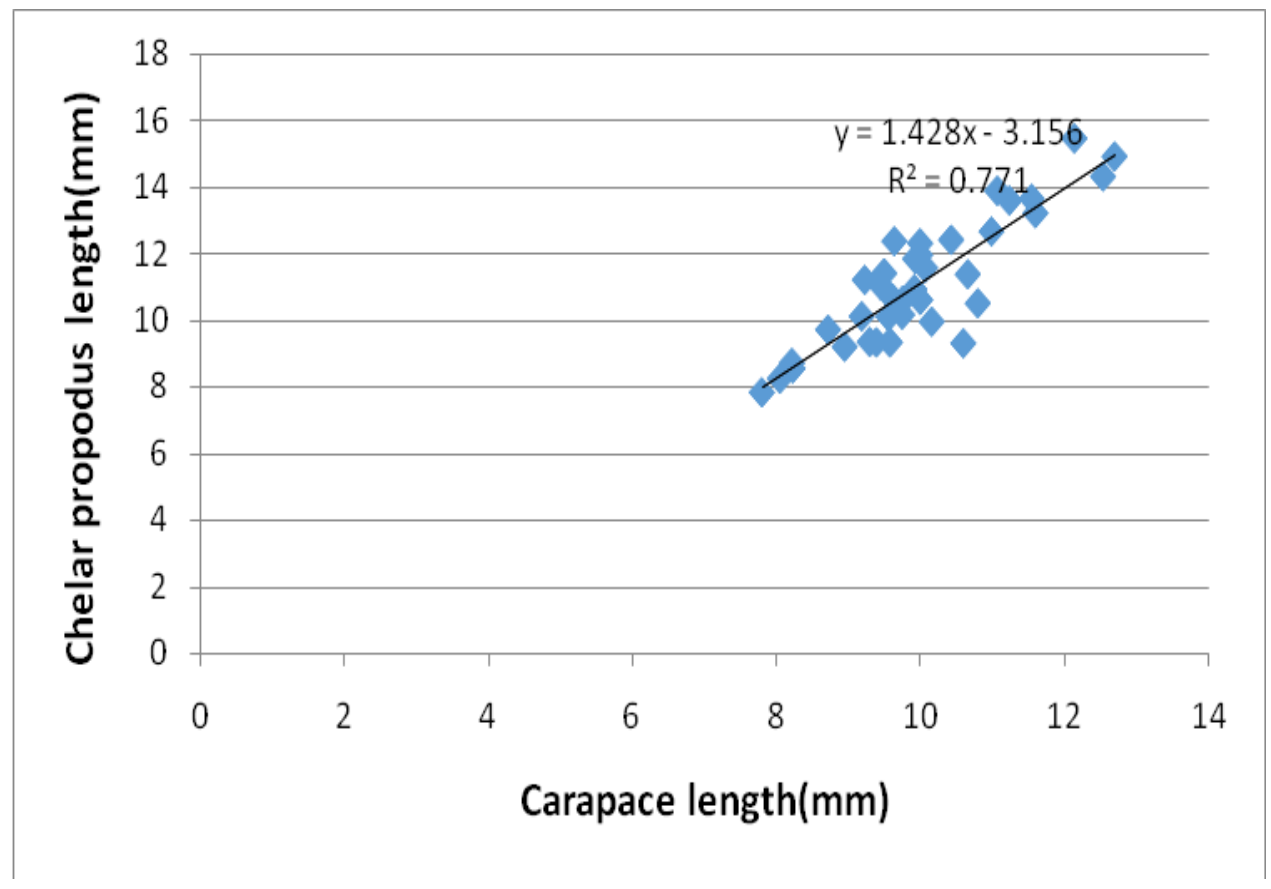

Fig.4 Carapace length and chela propodus height relationship in males of Scylla serrate

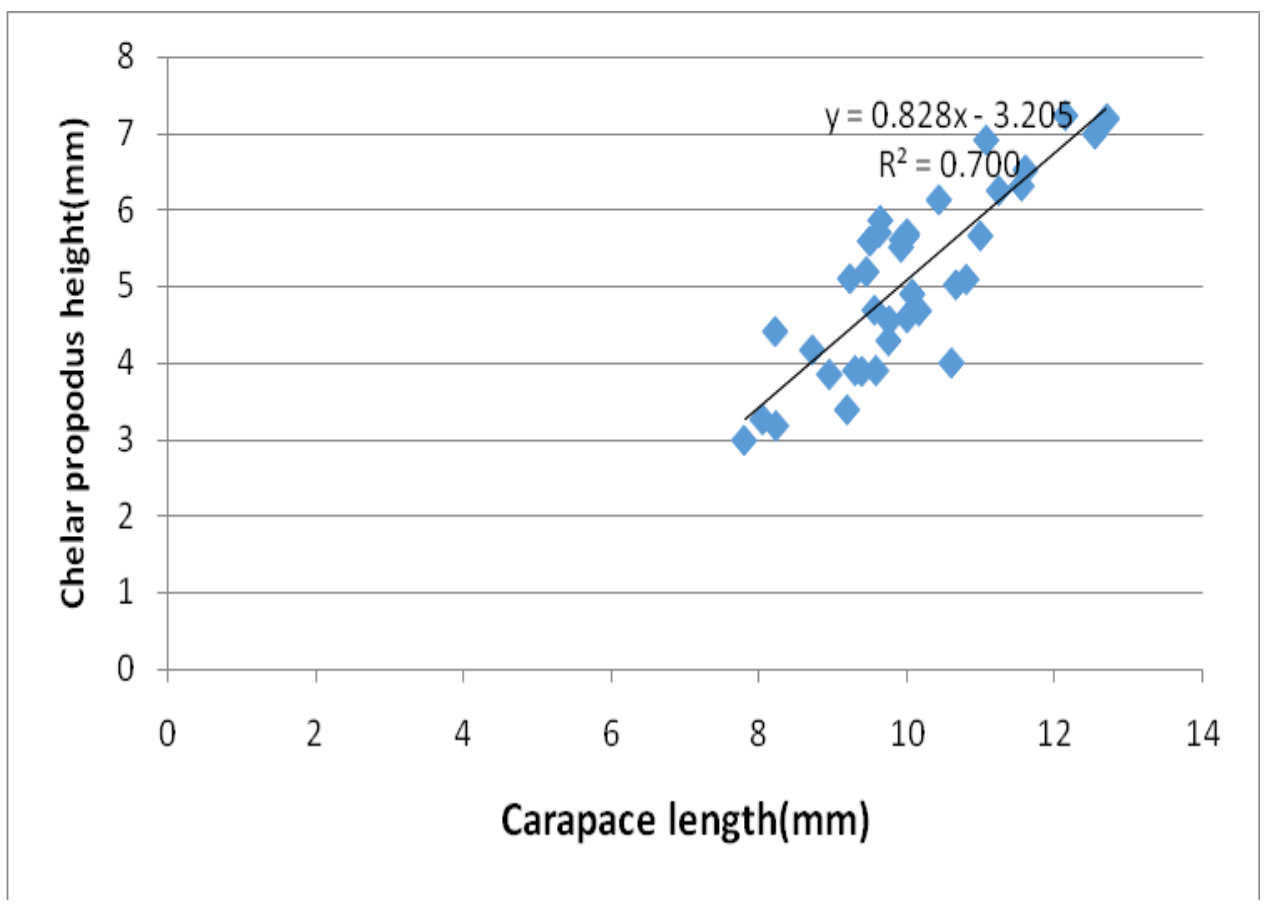


Fig.5 Chela propodus length and chela propodus height relationship in males of Scylla serrate

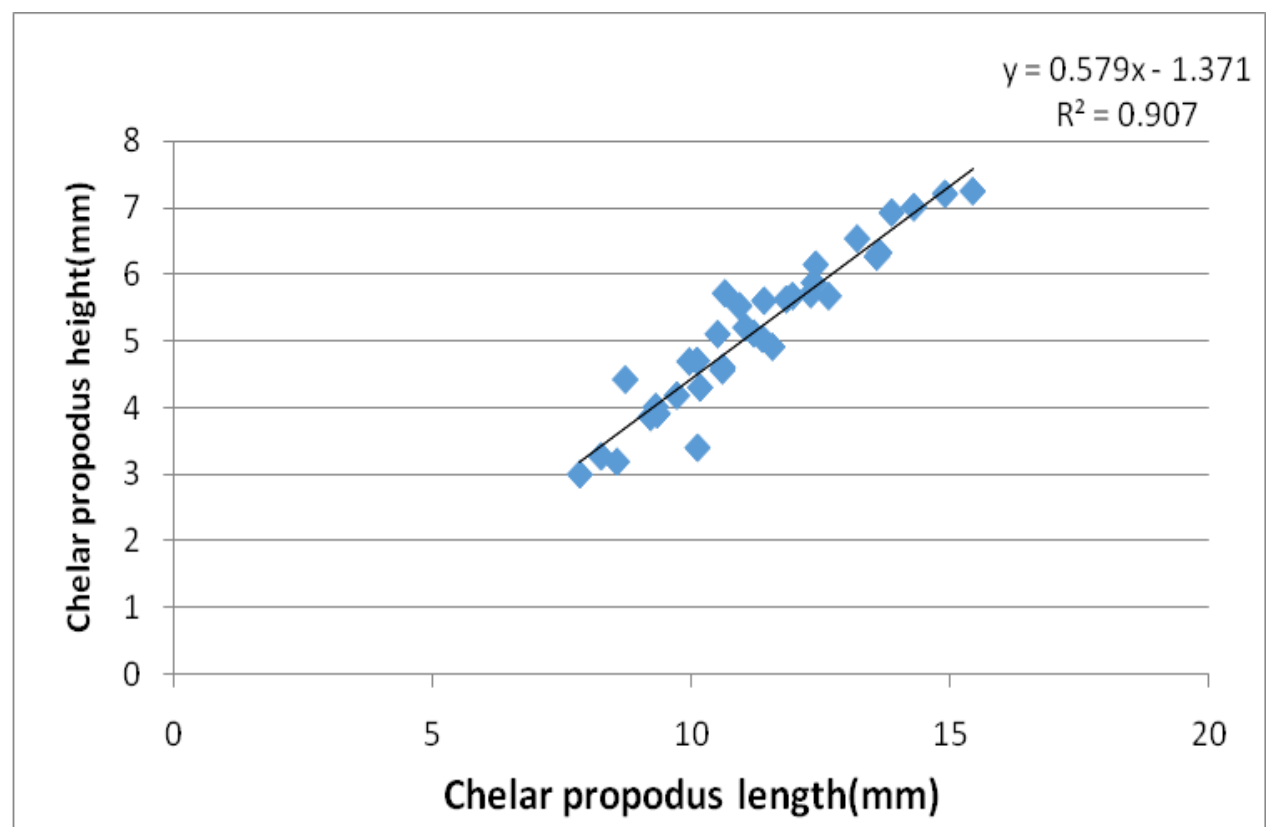

Fig.6 Carapace width and abdomen width relationship in females of Scylla serrate

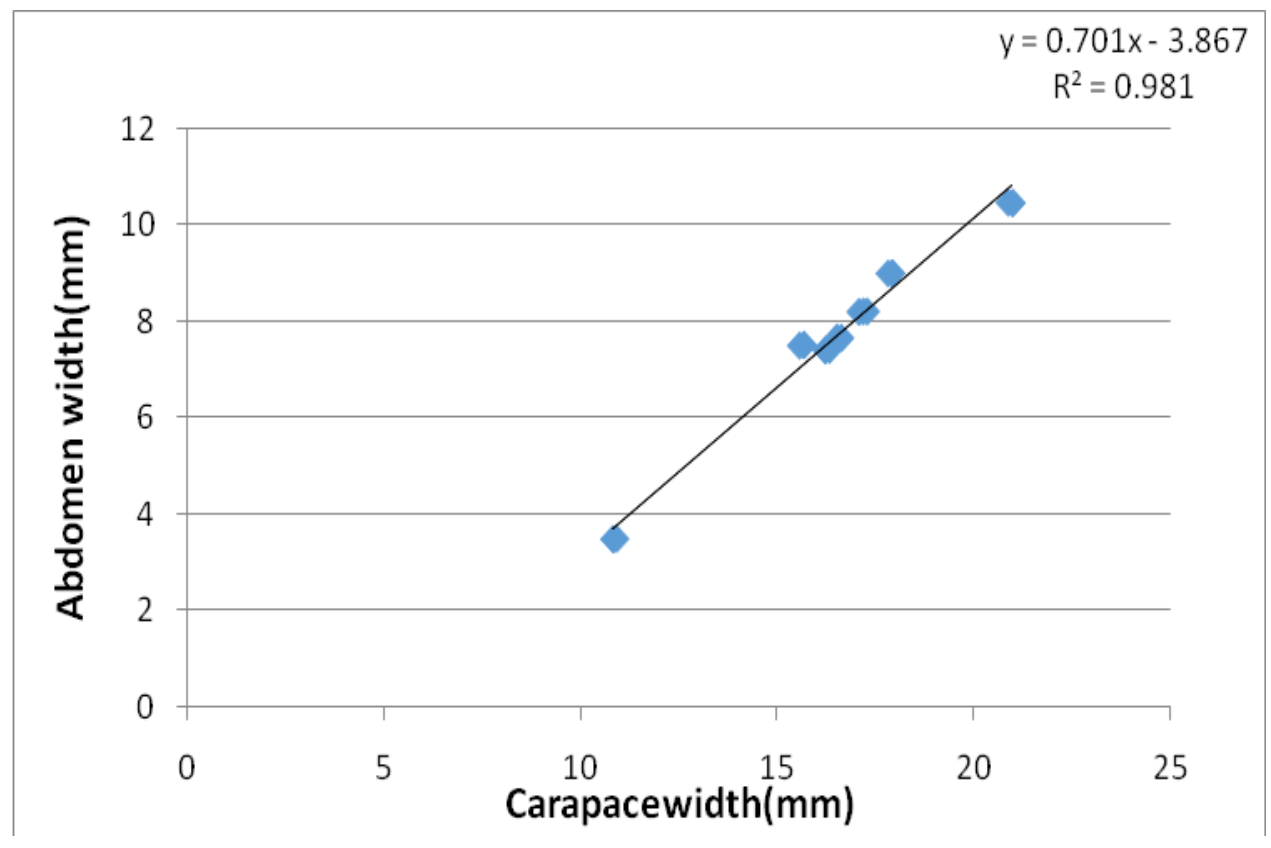


Fig.7 Carapace width and abdomen length relationship in females of Scylla serrate

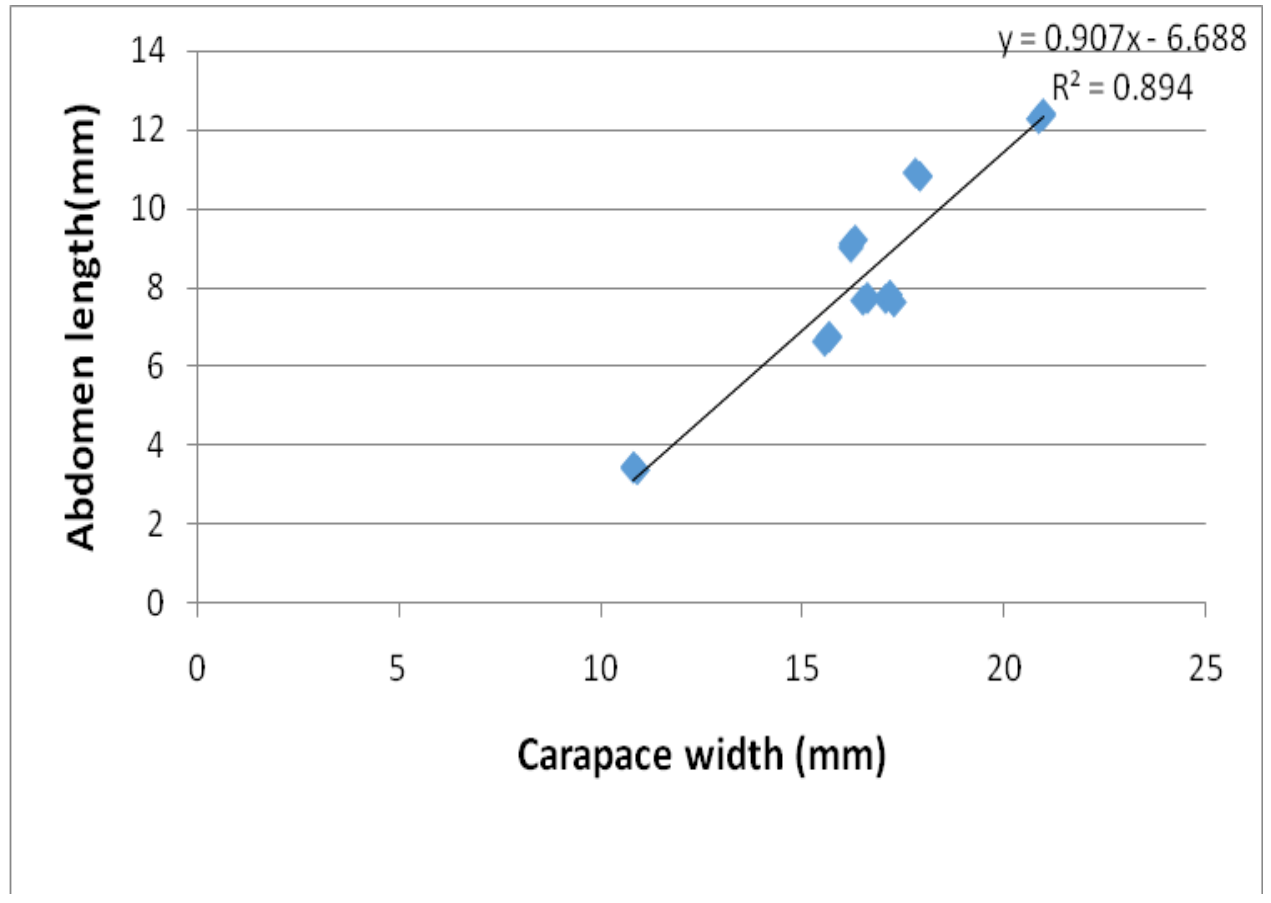

Fig.8 Carapace length and abdomen length relationship in females of Scylla serrate

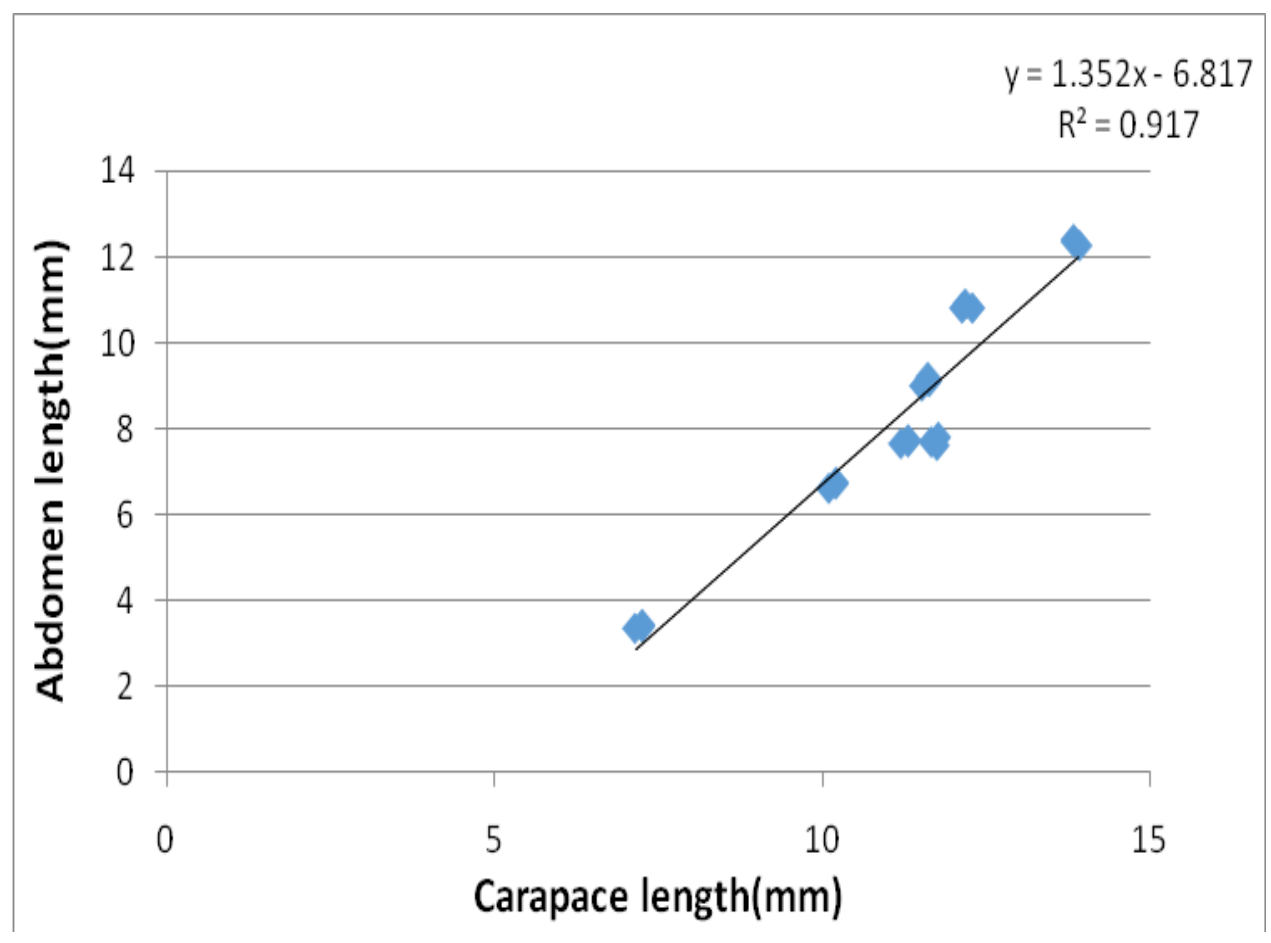


Fig.9 Carapace length and abdomen width relationship in females of Scylla serrate

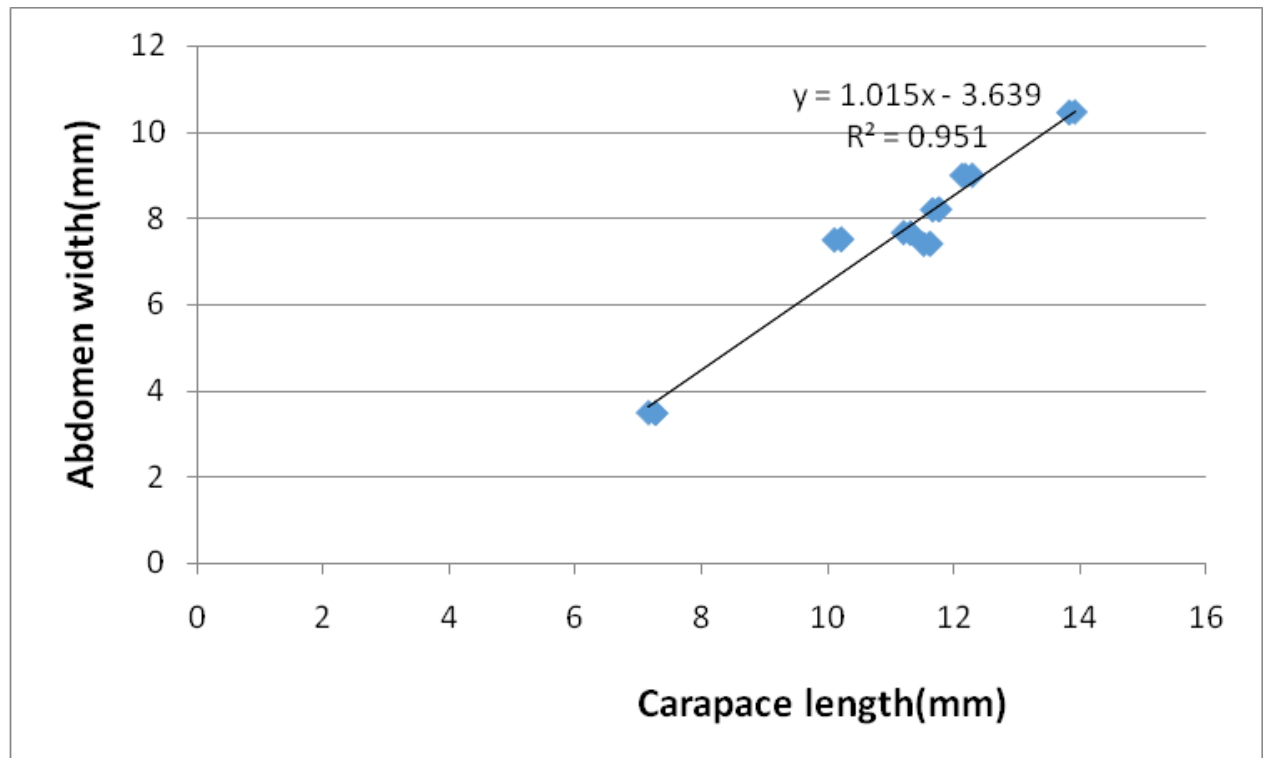

Fig.10 Abdomen width and abdomen length relationship in females of Scylla serrate

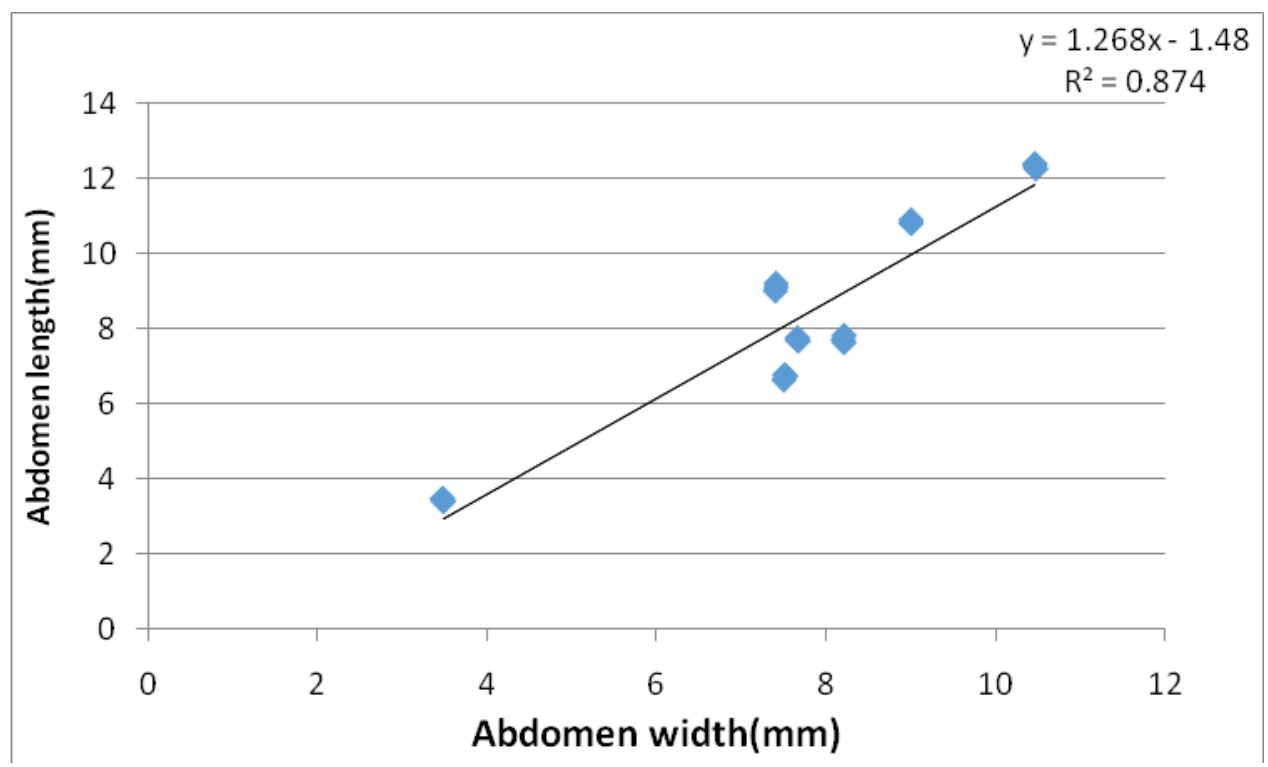


Fig.11 Carapace length- width relationship in Scylla serrate

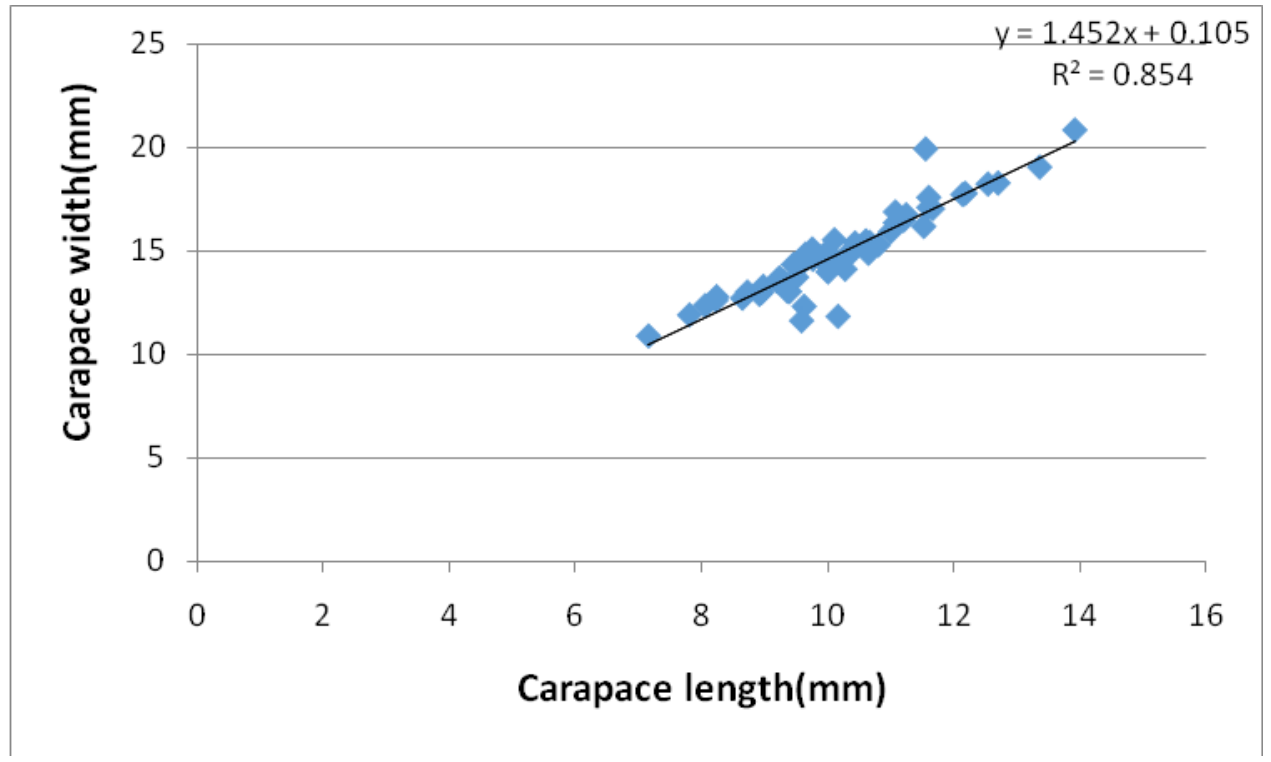

Fig.12 Carapace length-weight relationship in Scylla serrate

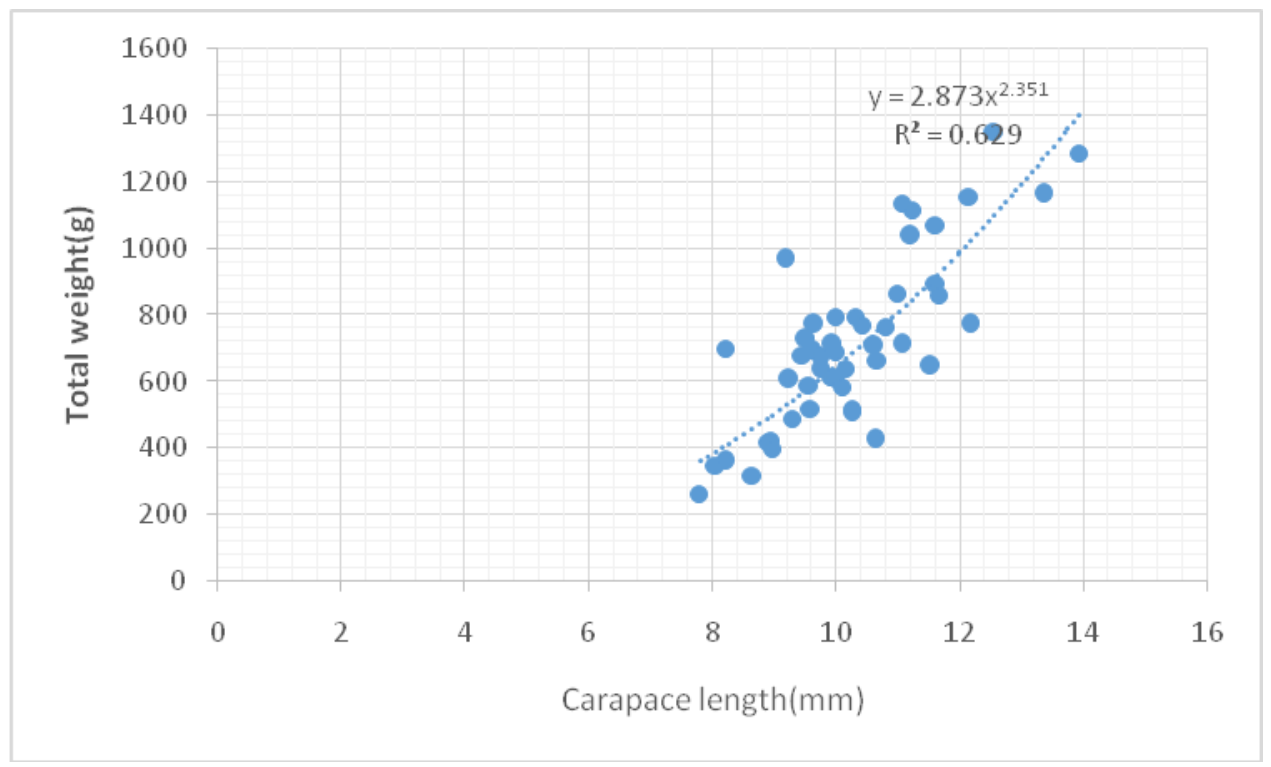


Fig.13 Relationship between carapace width and total weight in Scylla serrate

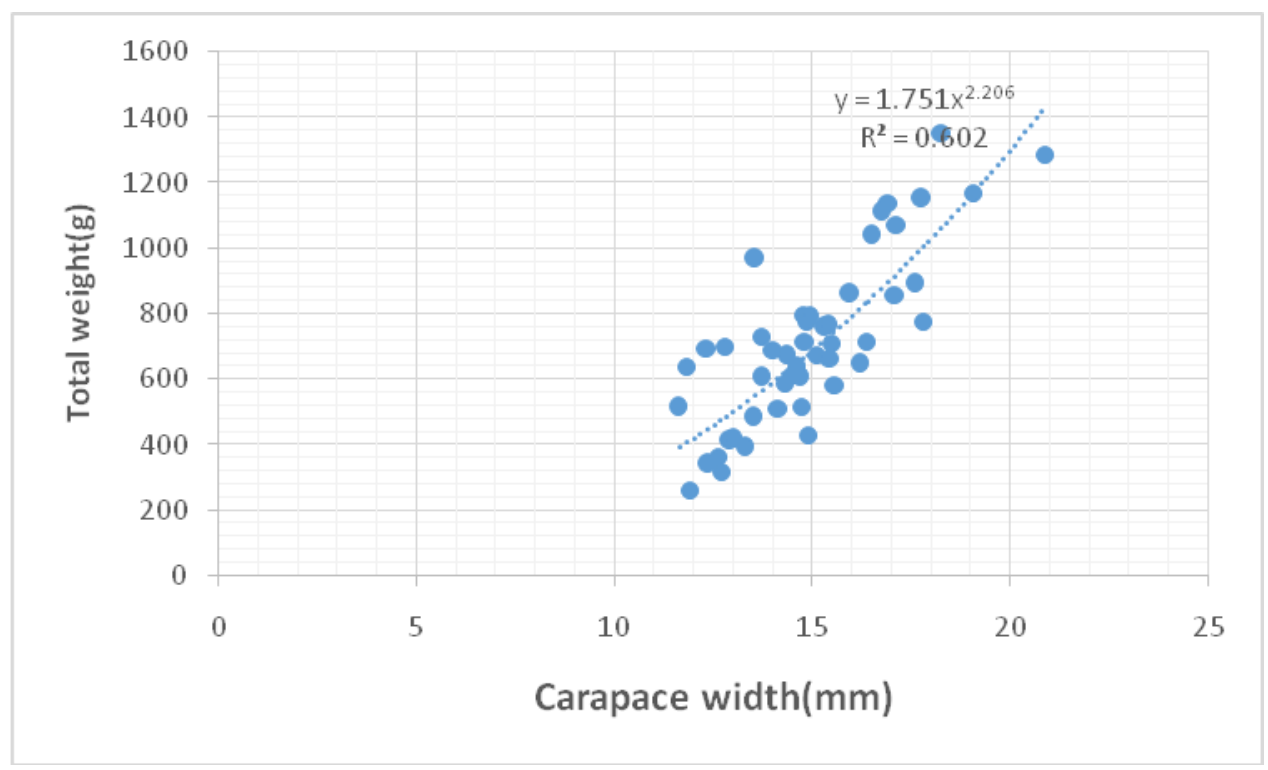

The relationship was positive and highly significant and $\mathrm{R}^{2}$ is relatively high for Carapace length against a Carapace width table 4.

In this study the results of the carapace width/length - weight relationship indicate that weight gain is almost uniform. $\mathrm{R}^{2}$ is relatively was less strong (Table 5 and 6).

In conclusions, consequently, the results of the length /width-weight relationships presented here will enable crab biologists to derive length estimates for mud crabs that are weighed but not measured. Hence the results of the study will make useful information, needed for the effective management and utilization of this resource in this area. And will be useful in comparing the different stocks of the same species at different geographical.

\section{Acknowledgements}

I wish to express my sincere gratitude to the staff of the Red Sea Fisheries Research Station for encouragements and their help during the fieldwork. This work was supported by the Animal Resources Research Corporation and the fisheries Research Center.

\section{References}

Atar, H. H. and Sector, S.(2003). Width/lengthweight relationships of the blue crab (Callinectes sapidus Rathbun, 1896) population living in Beymeleklagoon lake. Turkish Journ. Vet. Anim. Sci., 27: 443-447.

Cadrin, S. X. (2000). Advances in morphometric identification of fishery stocks. Reviews in Fish Biology and Fisheries, 10: 91-112.

Castiglioni, D.S., de Oliveira, P.J.A., Silva, J.S.S. and Coelho, P.A. (2011). Population dynamics of Sesarma rectum (Crustacea: Brachyura: Grapsidae) in the Arinquindá River mangrove, northeast of Brazil. J. Mar. Biol. Ass. U.K., 91: 1-7.

Costa, T. and. Soares-Gomes, A.S. (2008). Relative growth of the fiddler crab Ucarapax (Smith) (Crustacea: Decapoda: Ocypodidae) in a tropical lagoon (Itaipu), southeast Brazil. Pan-Am. J. Aquat. Sci., 3(2): 94- 100.

De Grave, S., Pentcheff, N.D., Ahyong, S.T., 
Chan, T.Y., Crandall, K.A., Dworschak, P.C., Felder, D.L., Feldmann, R.M., Fransen, C.H.J.M., Goulding, L.Y.D., Lemaitre R., Low, M.E.Y, Martin, J.W., Ng, P.K.L, Schweitzer, C.E., Tan, S.H., Tshudy, D. and Wetzer, R. (2009). A classification of living and fossil genera of decapods crustaceans. Raffles Bull. Zool. Suppl. 21: 1-109.

Gorce, G., Erguden, D., Sangun, L., Cekic, M. and Alagoz, S. (2006). Width/length and relationships of the blue crab (Callinectes sapidus Rathbun, 1986) population living in Camlik Lagoon Lake (Yumurtalik). Pakistan Journ. biol. Sci., 9(8): 14601464.

Hamed, A. El-Serehy, Mohamed, H.,Abd AlHameid, K., Al-Rasheid, A. and Mohamad, M. G. (2012). Brachyuran crabs (Crustacea: Decapoda) in the Suez Canal, Egypt, and their associated epifauna. Scientific Research and Essays Vol. 7(42), pp. 3665-3672.

Hartnoll, R.G. (1982). Growth. In: E.D. Bliss (ed.). The biology of Crustacea: embryology, morphology and genetics. Academic Press, New York, 2: 11-196.

Josileen, J. (2011). Morphometrics and lengthweight relationship in the Blue Swimmer Crab, Portunus Pelagicus Central Marine Fisheries Research Institute, P.O. Box 1603, Cochin-682 018, India.

Leme, M.H.A. (2005). Size at sexual maturity of female crabs Sesarma rectum Randall (Crustacea, Brachyura) and ontogenetic variations in the abdomen relative growth. Rev. Bras. Zool., 22(2): 433-437.

Moutopoulos, D. K. and Stergiou, K. I. (2002). Weight-length and length-length relationships for 40 fish species of the Aegean Sea (Hellas). Journ. appl. Ichthyol., 18: 200-203.

Ng, P.K.L., Guinot, D., Davie, P.J.F. (2008). Systema Brachyurorum: Part 1. An annotated checklist of extant Brachyuran crabs of the world. Raffles Bull. Zool. Suppl. 17: 1-286.

Ribeiro, F. B., Cascon, H. M. and Bezerra, L. E. A.(2013).Morphometric sexual maturity and allometric growth of the crab Sesarma rectum Randall, 1840 (Crustacea: Sesarmidae) in an impacted tropical mangrove in northeast Brazil. 41(2): 361-368, Brazilian Congress of Marine Biology DOI: 10.3856/vol41issue2-fulltext-15.

Sangun, L., Tureli, C., Akamca, E. and Duysak, O. (2009). Width/length-weight and width length relationships for 8 crab species from north-Mediterranean coast of Turkey. Journal of Animal and Veterinary Advances, 8(1): 75-79.

Shelley, C.; Lovatelli, A. (2011). Mud crab aquaculture - A practical manual. FAO Fisheries and Aquaculture Technical Paper. No. 567. Rome, FAO. 78 pp.

Vine, P. J. and Vine, M. P. (1980). Ecology of Sudanese Coral Reefs with particular reference to reef morphology and distribution of fishes Proceeding of Symposium on the Coastal and Marine Environment of the Red Sea, Gulf of Aden and Tropical Western Indian Ocean, Volume 1pp 88:140.

https://www.dpi.nsw.gov.au/_data/assets/pdf... /Giant-Mud-Crab.pdf status of fisheries resources in nsw 2008. giant mud crabs p147.

\section{How to cite this article:}

Hala Gindeel Abu Bakr Ahmadoon. 2019. Morphometric and Length-Weight Relationship in the Mud Crab (Scylla serrata) from Sudanese Red Sea Coast. Int.J.Curr.Microbiol.App.Sci. 8(06): 3240-3253. doi: https://doi.org/10.20546/ijcmas.2019.806.386 